Artigo

\title{
Analysis and Distribution of the Rainfall Monitoring Network in a Brazilian Pantanal Region
}

\author{
Marcia Ferreira Cristaldo ${ }^{1}$, Celso Correia de Souza ${ }^{2}$, Leandro de Jesus ${ }^{1}$, \\ Carlos Roberto Padovani ${ }^{3}$, Paulo Tarso Sanches de Oliveira ${ }^{4}$, Hevelyne Henn da Gama Viganó ${ }^{5}$ \\ ${ }^{1}$ Departamento da Computação, Instituto Federal de Educação, Ciência e Tecnologia \\ de Mato Grosso do Sul, Aquidauana, MS, Brasil. \\ ${ }^{2}$ Universidade Anhanguera UNIDERP, Campo Grande, MS, Brasil. \\ ${ }^{3}$ Departamento de Geoprocessamento, Empresa Brasileira de Pesquisa Agropecuária, \\ Corumbá, MS, Brasil. \\ ${ }^{4}$ Faculdade de Engenharias, Arquitetura e Urbanismo e Geografia, \\ Universidade Federal de Mato Grosso do Sul, Campo Grande, MS, Brasil. \\ ${ }^{5}$ Departamento de Matemática, Instituto Federal de Educação, \\ Ciência e Tecnologia de Mato Grosso do Sul, Campo Grande, MS, Brasil.
}

Received in May 15, 2015 - Accepted in March 10, 2017

\begin{abstract}
To better understand drought and flood dynamics in the Pantanal is crucial an adequate hydrometeorological monitoring network. However, few studies have investigated whether the current monitoring systems are suitable in this region. Here, we analyzed the hydrometeorological monitoring network of the Aquidauana region, composed of pluviometric, meteorological and fluviatile gauging stations. We obtained data of all hydrometeorological gauges available in this region to compare with the World Meteorological Organization (WMO) recommendation. We found that although the number of stations in operation is satisfactory when compared with that established by the WMO, the network is not satisfactory in the operating stations because of lack of maintenance, thus creating a need for additional stations. This fact was also observed when analyzing the meteorological network. Using remote sensing data may be possible to fill these data gap. However, to improve the knowledge on hydrological processes in this region is still necessary to install additional ground-based stations.
\end{abstract}

Keywords: pluviometric stations, rainfall density, Aquidauana.

\section{Análise e Distribuição da Rede de Monitoramento de Chuvas na Região do Pantanal Brasileiro}

\section{Resumo}

Para entender melhor a dinâmica de seca e inundação no Pantanal é fundamental uma rede de monitoramento hidrometeorológico adequada. No entanto, poucos estudos têm investigado se os atuais sistemas de monitoramento são adequados nesta região. Aqui, analisamos a rede de monitoramento hidrometeorológico da região de Aquidauana, composta por estações pluviométricas, meteorológicas e fluviais. Obtivemos dados de todos os medidores hidrometeorológicos disponíveis nesta região para comparação conforme a recomendação da Organização Meteorológica Mundial (OMM). Constatou-se que, embora o número de estações em operação seja satisfatório quando comparado com o estabelecido pela OMM, a densidade da rede não é satisfatória nas estações de operação por falta de manutenção, criando assim a necessidade de estações adicionais. Esse fato também foi observado na análise da rede meteorológica. O uso de dados de sensoriamento remoto pode ser possível para preencher essa lacuna de dados. No entanto, para melhorar o conhecimento sobre os processos hidrológicos nesta região ainda é necessário instalar estações terrestres adicionais. Palavras-chave: estação pluviométrica, densidade de chuva, Aquidauana.

Autor de correspondência: Marcia Ferreira Cristald, omarcia.cristaldo@ifms.edu.br, mferreiracristaldo@gmail. 


\section{Introduction}

The water crisis throughout the world, and particularly in Brazil, has brought up discussions regarding the conscious use of natural resources. Other existing water reserves in the country are being considered, as Brazil has some of the largest rivers in the world and houses much of the Guarani Aquifer System - one of the largest underground reserves of fresh water that could possibly be one of the solutions for a good part of the country's water supply (Oliveira et al., 2016).

Proper management of potential water reserves available in the world requires knowledge of the fluviatile and pluviometric systems. This monitoring becomes a key activity to subsidize the management of water resources. On the other hand, the historical data series resulting from such activity allow monitoring weather and climate over the years, supporting projects of research on water resources.

Thus, the gathering of information necessary for hydrology is accomplished through hydrometeorological station networks, whose importance of data series is proportional to their temporal extent. In Brazil, many stations have recorded data for more than a hundred years, such as the pluviometric station of Morro Velho (Minas Gerais State) and the fluviatile gauging station of the River Negro in Manaus, with data recorded from 1855 and 1902, respectively. The first activities of hydrological data collection performed in an organized manner, however, date back to the early $20^{\text {th }}$ century, more precisely, 1920, when the Commission of Hydraulic Forces Studies built stations addressed to specific studies of hydraulic use, aiming at hydroelectric power. The register of hydrometric stations in the country started around 1968 by the former DNAEE (National Department of Water and Power) with publications of the first inventory of fluviatile and pluviometric stations (Ishihara, 2014).

According to the ANA (National Water Agency), the National Basic Hydro-meteorological Network has 2,527 pluviometric stations that measure rainfall at a given point. By means of an ambitious project, ANA is planning the national hydro-meteorological network from those in operation and in partnership with the various agencies and interested states (Ana, 2015). In 1997 the PCBAP (Conservation Plan of the Upper Paraguay Basin) in 1997 started a study on the pluviometric stations: they totaled 214 stations, 22 of which deactivated. Therefore, at the time of the survey 192 stations were operating in the region (Tucci, 2012).

The area investigated in the present study is inserted within the BAP - Upper Paraguay Basin - (which is the fluvial channel of the River Aquidauana). The Aquidauana basin has a significant importance for the sub-basin of the River Miranda, a tributary of the River Paraguay in the State of Mato Grosso do Sul. Located by the homonymous river, the city of Aquidauana began its process of urban development along its banks. The urban territorial expansion led to significant changes in the natural landscape, showing many current social and environmental problems; flood is a case in point. The frequent occurrence of either flood or drought results in severe losses of livestock and crops. The inundation interrupts land transportation, and the dry weather accelerates the river erosion because of the heavy uncontrolled river traffic (Willink et al., 2009).

It is therefore extremely important to find a suitable method of flood forecasting to help plan a sustainable socioeconomic management system for local development. However, it is necessary to analyze the conditions of the meteorological data provided by the pluviometric and fluviatile networks in operation so that a suitable methodology for forecasting weather events can be developed. Despite to the importance of this evaluation, few studies have investigated whether the current monitoring systems are suitable in this region

The objectives of this study are to analyze the rain gauges network distribution in the region of Aquidauana and to check whether the current installed ground-based stations are sufficient to monitor the region.

\section{Area of Study}

The Aquidauana basin is bordered by the River Paraná basin to the south and east; by the River Negro basin to the north; and by the River Miranda basin, of which it is a tributary, to the west (Fig. 1). The basin is divided into two distinct areas: the northern part, that is drained by the upper reaches of the River Aquidauana itself, coated with quartz sands that have high susceptibility to erosion; and the southern part, drained by the tributaries of the left bank downstream the Salobra brook, predominated by silt and clay soils. A large part of this area houses pastures for cattle and potentially irrigable agricultural areas.

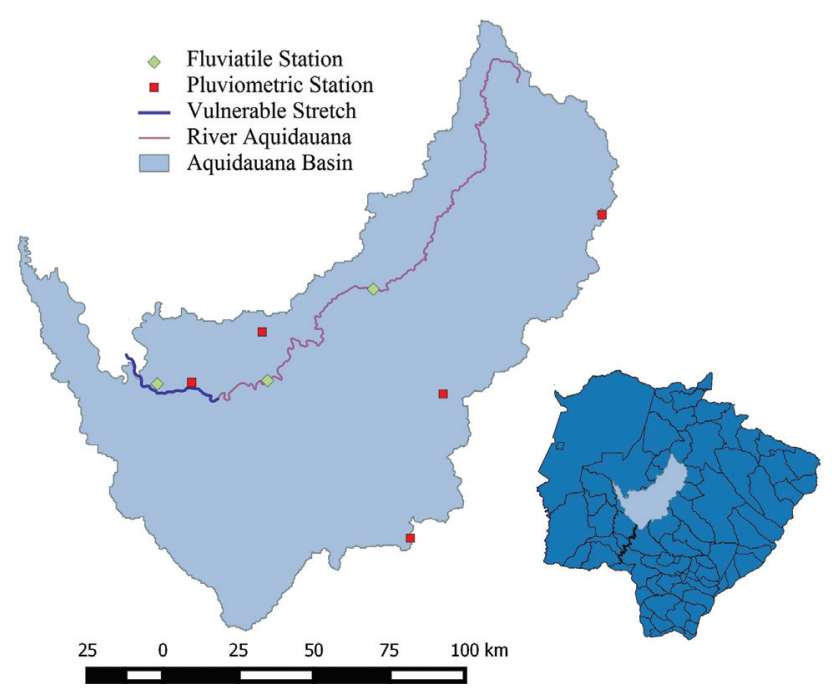

Figure 1 - River Aquidauana Basin, with pluviometric stations marked in red and the fluviatile ones marked in green. 
The River Aquidauana (Fig. 1) has a privileged location; its natural resources pose a great potential for tourism and a good reserve for fisheries. Covering $286 \mathrm{~km}$ in the study area, the River Aquidauana is the main tributary of the River Miranda and one of BAPs main streams. It starts in the surroundings of Serra de Maracaju, in the plateaus of São Gabriel do Oeste county, altitude of $715 \mathrm{~m}$, crossing plateaus and reaching the city of Aquidauana at an altitude of $133 \mathrm{~m}$, with its mouth in the River Miranda at $90 \mathrm{~m}$.

\section{Methodology}

The Hydro System was used in this work as a source of information on pluviometric and fluviatile stations in the Aquidauana region, made available online by the ANA via the HidroWeb System.

The HidroWeb system allows, among other things, a) managing a hydro-meteorological database stored in a relational database; b) entering data by agencies that operate a hydro-meteorological network; c) analyzing the consistency of fluviatile data and its handling; d) generating historical data series of limnimetric quotas; and e) calculating the basic statistical functions necessary for determining the periods of maximum ebb-tide and flood. This system carries two types of hydro-meteorological data: inventory data (rivers and stations), and historical data series (daily measurements of quotas and rain). The data are grouped into basic processing units called records (Ana, 2015).

To analyze data generated by rainfall and river flow networks of the Aquidauana region, we used spreadsheets with data from the operation period of each station. The spreadsheets were subdivided interspersing the operating periods of the stations, given the long data series of some stations. It was possible to adopt a classification criterion of annual records for complete or incomplete information because of yearly data for most series of records.

\subsection{Distribution and density of pluviometric stations}

To analyze the distribution and density of pluviometric stations in the basin, we used the methodology recommended by the World Meteorological Organization (WMO), according to the following criteria: (a) international experience; (b) the main objectives of the desired accuracy, and (c) the dominant meteorological characteristics in the region (Wmo, 1994).

By systematizing in tables the information made available by the stations we have tried to establish a profile of spatial and sectorial distribution of the rainfall network in the region. The criterion is based on groups defined by the WMO considering population density. It is based on the international experience of a large number of countries and covers a broad spectrum of different demographic, geographic, morphological and climate conditions. Such network is not ideal but the method suggests a lower limit for a network with reasonable density. A rainfall network with reasonable density should be within the confidence groups. Fig. 2 shows a graph of relative population density plotted against the density of the pluviometric stations in operation.

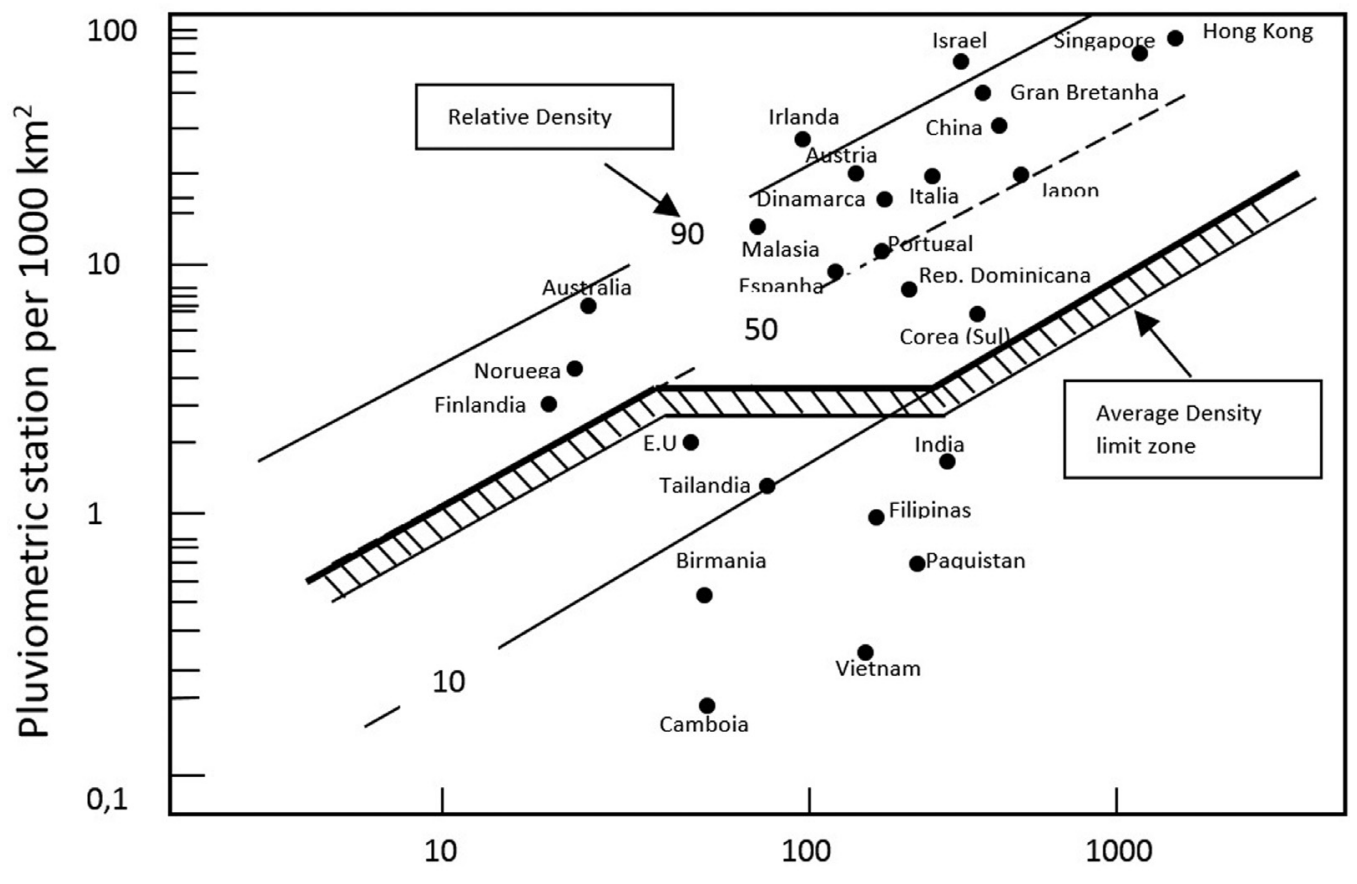

Population Density per $1000 \mathrm{~km}^{2}$

Figure 2 - Relative density of pluviometric networks according to the WMO. Source: Wmo (1994). 
With regards to the codes of responsible agencies and operators, Table 1 lists the codes and the respective agencies used in this study.

\subsection{Inventory of pluviometric stations}

It is important to know the number of pluviometric stations, their operation and proper maintenance to subsidize studies related to the maximum use of water resources in various aspects. In the BAP, the main interests are the issues of navigation, flood warnings, hydroelectric plants, water supply and its role in biodiversity conservation, and also the preservation of scenic value. In addition to these concerns, in the Aquidauana region there has to be considered the riverside population, which have been affected by the floods.

Table 2 shows the information of the rain gauges in the Aquidauana sub-basin.

The stations providing rainfall indices that influence the level of the River Aquidauana quota in Aquidauana city are: Palmeiras, Santa Elisa, Rochedo and Bandeirantes. The other stations are located either upwards the city or on rivers that flow into the River Miranda or Taboco

The WMO used a criterion that assesses the number of stations per $\mathrm{km}^{2}$ considering population density. The analysis of the rainfall monitoring network was conducted in order to provide the Aquidauana region with a sufficiently dense network that would make it possible to accurately characterize the rainfall system in a uniform and systematic manner. Two criteria were taken into account: population density and minimum density for pluviometric stations.

i) Population density

Following the international experience, a reasonable density network should be located within the confidence groups defined by the WMO (see Fig. 3). Thus, the density of stations (number of stations per $1,000 \mathrm{~km}^{2}$ ) and the population density (number of inhabitants per $\mathrm{km}^{2}$ ) were calculated for the region. The calculated

Table 1 - List of codes and responsible agencies and operators.

\begin{tabular}{lcc}
\hline Code & Acronym & Name \\
\hline 001 & ANA & Agência Nacional de Águas - Water National Agency \\
005 & INMET & Instituto Nacional de Meteorologia - National Institute of Meteorology \\
082 & CPRM & Companhia de Pesquisa de Recursos Minerais - Company of Research on Mineral Resources \\
099 & OTHERS & Other agencies \\
110 & 396 & Resolution 396/98 ANEEL \\
293 & CEMTEC & Centro de Monitoramento de Tempo, do Clima e dos Recursos Hídricos - Center for Monitoring \\
500 & Weather, Climate and Water Resources \\
\hline
\end{tabular}

Table 2 - Information collected for sub-basin pluviometric stations.

\begin{tabular}{|c|c|c|c|c|c|c|c|c|c|c|}
\hline \multirow[t]{2}{*}{ Order } & \multirow[t]{2}{*}{ Code } & \multirow[t]{2}{*}{ Station } & \multirow[t]{2}{*}{ River } & \multirow{2}{*}{$\begin{array}{l}\text { City of Mato } \\
\text { Grosso do } \\
\text { Sul }\end{array}$} & \multirow{2}{*}{$\begin{array}{l}\text { Altitude } \\
\text { (m) }\end{array}$} & \multirow{2}{*}{$\begin{array}{l}\text { Company } \\
\text { in charge }\end{array}$} & \multirow{2}{*}{$\begin{array}{l}\text { Operating } \\
\text { company }\end{array}$} & \multicolumn{2}{|c|}{ Coordinates } & \multirow{2}{*}{$\begin{array}{c}\text { In operation } \\
\text { or Suspended } \\
\quad(\mathrm{IO} / \mathrm{S})\end{array}$} \\
\hline & & & & & & & & Latitude & Longitude & \\
\hline 1 & 01954002 & Rochedo & Aquidauana & Rochedo & 447 & 005 & 082 & $19^{\circ} 57^{\prime} 09$ & $54^{\circ} 53^{\prime} 34$ & S \\
\hline 2 & 01954005 & Bandeirantes & Aquidauana & Bandeirantes & 456 & 005 & 082 & $19^{\circ} 55^{\prime} 04$ & $54^{\circ} 21^{\prime} 31$ & IO \\
\hline 3 & 01955000 & Iguaçu & Taboco & Aquidauana & 130 & 005 & 082 & $19^{\circ} 56^{\prime} 41$ & $55^{\circ} 47^{\prime} 40$ & $\mathrm{~S}$ \\
\hline 4 & 01956002 & Rio Negro & Taboco & Anastácio & 106 & 001 & 082 & $19^{\circ} 34^{\prime} 00$ & $56^{\circ} 12^{\prime} 00$ & S \\
\hline 5 & 01954003 & Rio Negro & Taboco & Rio Negro & 233 & 001 & 082 & $19^{\circ} 26^{\prime} 23$ & $54^{\circ} 59^{\prime} 00$ & S \\
\hline 6 & 01956003 & Entre Rios & Aquidauana & Aquidauana & 103 & 001 & 082 & $19^{\circ} 41^{\prime} 48$ & $56^{\circ} 16^{\prime} 58$ & IO \\
\hline 7 & 01956008 & S. Sebastião & Paraguai & Aquidauana & 105 & 001 & 082 & $19^{\circ} 21^{\prime} 33$ & $56^{\circ} 24^{\prime} 33$ & IO \\
\hline 8 & 02055000 & Aquidauana & Aquidauana & Aquidauana & 155 & 005 & 005 & $20^{\circ} 27^{\prime} 24$ & $55^{\circ} 40^{\prime} 17$ & $\mathrm{~S}$ \\
\hline 9 & 02055001 & Cipolância & Taboco & Aquidauana & 171 & 005 & 082 & $20^{\circ} 07^{\prime} 40$ & $55^{\circ} 23^{\prime} 36$ & $\mathrm{~S}$ \\
\hline 10 & 02055002 & Palmeiras & Aquidauana & Aquidauana & 175 & 005 & 082 & $20^{\circ} 26^{\prime} 56$ & $55^{\circ} 25^{\prime} 51$ & IO \\
\hline 11 & 02055003 & Faz. Lajeado & Aquidauana & Dois I.Buriti & 104 & 005 & 082 & $20^{\circ} 17^{\prime} 32$ & $55^{\circ} 26^{\prime} 43$ & IO \\
\hline 12 & 02055007 & Aquidauana & Aquidauana & Aquidauana & 155 & 001 & 001 & $20^{\circ} 27^{\prime} 31$ & $55^{\circ} 46^{\prime} 51$ & S \\
\hline 13 & 02055006 & Aquidauana & Aquidauana & Aquidauana & 155 & 293 & 293 & $20^{\circ} 27^{\prime} 11$ & $55^{\circ} 40^{\prime} 15$ & $\mathrm{~S}$ \\
\hline 14 & 02054009 & Santa Elisa & Aquidauana & Terenos & 411 & 001 & 082 & $20^{\circ} 29^{\prime} 26$ & $54^{\circ} 52^{\prime} 18$ & IO \\
\hline 15 & 02154005 & S. Francisco & Brilhante & Aquidauana & 445 & 001 & 500 & $21^{\circ} 00^{\prime} 00$ & $54^{\circ} 00^{\prime} 00$ & S \\
\hline
\end{tabular}




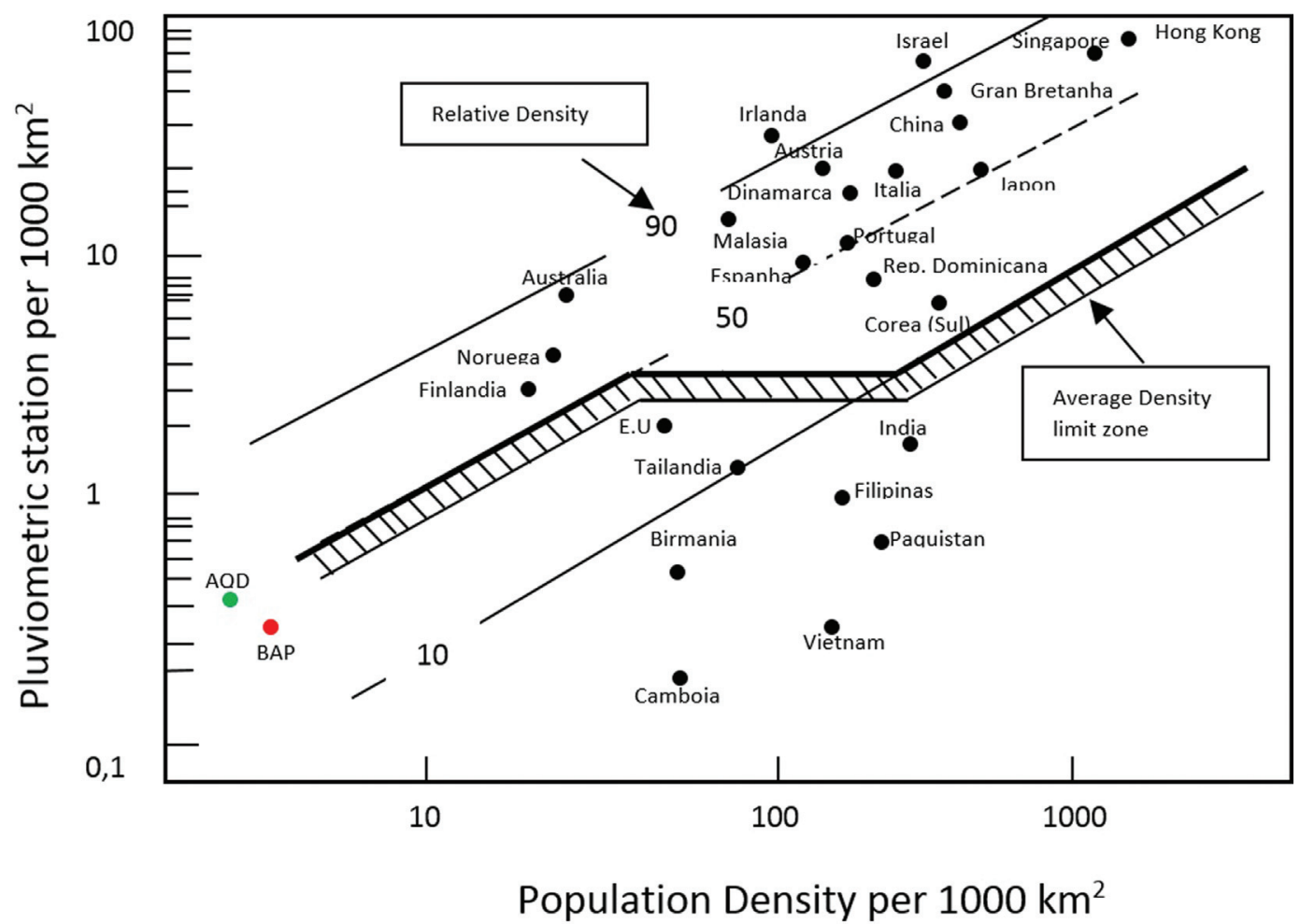

Figure 3 - Relative density of rainfall networks of the Aquidauana (AQD) region (in red) and Upper Paraguay Basin (in green). Source: Adapted from Loureiro et al. (2012).

values for density of the stations were then compared with those recommended by the method to check the minimum density of the network.

ii) Minimum density for pluviometric stations

The density of stations (area of $\mathrm{km} 2$ by number of stations) was calculated for the region and compared with the minimum recommended by the Wmo (1994) (Table 3).

\section{Results and Discussion}

The hydrographic region of Mato Grosso do Sul occupies an area of $173,874.68 \mathrm{~km} 2$, corresponding to $48 \%$ of the BAP. The Upper Paraguay Basin comprises an area corresponding to half of the state. In the surrounding highlands (above altitude of $200 \mathrm{~m}$ ) lie the sources of the main rivers

Table 3 - Recommendation of minimum density of pluviometric stations.

\begin{tabular}{lc}
\hline Physiographic Unit & $\begin{array}{c}\text { Minimum density } \\
\text { (area in } \mathrm{km}^{2} \text { covered by each station) }\end{array}$ \\
\hline Coast & 2,750 \\
Mountainous region & 1,000 \\
Inland Plain & 1,875 \\
Undulating region & 1,875 \\
Small islands & 3,000 \\
Arid region & 20,000 \\
\hline
\end{tabular}

that make up the great plain, an area below altitude of $200 \mathrm{~m}$, with low drainage capacity, hence subject to major flooding (Ishihara, 2014).

The studied area is located on the Miranda basin, that belongs to the BAP, specifically the upper sub-basin of the River Aquidauana, with an area of 21,983.00 $\mathrm{km}^{2}$ and a population of 46,998 inhabitants in 2014 (Ibge, 2015). The population density is 2.69 in habitants $/ \mathrm{km}^{2}$. To calculate the number of stations per $\mathrm{km}^{2}$, the nine operating stations in the area were considered, excluding the deactivated stations and those with missing data. Table 4 shows the results of this analysis.

It is worth noting that the basin comprising the River Aquidauana has a population density of 2.69 in habitants $/ \mathrm{km}^{2}$ (Table 4). A rainfall network with reasonable density must have two stations per $1,000 \mathrm{~km}^{2}$ for this range of population density (Fig. 3).

When plotting the data for the Aquidauana region in Fig. 3, we noted that the region is below of the recommended limit by the WMO. It is located between the lines demarcating the relative densities of $10 \%$ and $50 \%$, and is not included in the limit considered reasonable. We found the same for the BAP. A similar finding was reported by Loureiro et al. (2012) in their study on the Cerrado biome. Thus, the Aquidauana region is still below the number of stations per $1000 \mathrm{~km}^{2}$ established by the WMO. The region under study needs a monitoring network - one station every $1000 \mathrm{~km}^{2}$ - to measure the intensity of precipitation with 
Table 4 - Results of the analysis of rainfall monitoring network.

\begin{tabular}{lccccc}
\hline River Basin & Area $\left(\mathrm{km}^{2}\right)$ & Density $\left(\right.$ inhabitants $\left./ \mathrm{km}^{2}\right)$ & N. of stations & \multicolumn{2}{c}{ Network density } \\
\cline { 5 - 6 } & & & N. of stations $/ 1000 \mathrm{~km}^{2}$ & Area $\left(\mathrm{km}^{2} / \mathrm{station}\right)$ \\
\hline Paraguay & 363,446 & 4.80 & 130 & 0.35 & $2,786.60$ \\
Aquidauana & 21,983 & 2.69 & 9 & 0.42 & $2,442.55$ \\
\hline
\end{tabular}

quality. This problem does not apply in this region of study alone, but in several places around the world where the number of works that perform the monitoring of hydro meteorological data is decreasing (Burt and McDonnell, 2014). The use of these data for research is of great socioeconomic importance for the region, since it allows the planning not only of livestock, the main economic activity of the studied basin, but also of fishing, tourism and navigation.

Kidd et al. (2016) show that the area with operational rain gauges worldwide is surprisingly small, totaling only $0.00000000593 \%$ of the Earth's surface. There is a high number of rain gauges, but the actual number available to the user is considerably variable depending on the study period and latency requirements. Information that uses rainfall measurements with various input data from amateur networks has potential for many applications, including meteorology, but is probably more difficult to achieve due to timely data access, continuity, and absolute calibration of measurements.

Researchers are striving to obtain measurement data in regions with limited data, however, additional highquality measures are still required to fill gaps in certain regions. In particular, the interior of some continents such as South America, Africa and Oceania, and continental land regions in the Northern Hemisphere and Antarctica are deficient in precipitation meters (Muller et al., 2015). Projects such as the Trans-African Hydro-Meteorological Observatory (Tahmo, http://tahmo.org) are now beginning to meet this need.

To address the lack of data in regions outside the WMO recommended range, there are satellite observations where rainfall indices obtained from remote sensing have been available across the globe for more than 20 years. More specifically, satellite estimates are distinctly advantageous in assessing rainfall in regions with few data, such as oceans. Satellite observations of visible, infrared, and specially passive and active, microwave system are used to generate precipitation estimates using a number of techniques (Kidd et al., 2016). Several authors use remote sensing data to fill the lack of data and a monitoring network at some points in the study region (Hughes, 2006), (Dembélé and Zwart, 2016) and (Bodian et al., 2016).

Doing research and maintaining monitoring networks are expensive and require a lot of work. Thus, several researchers have failed to develop field studies and have invested more in modeling studies and used remote sensing data where only one computer is necessary. This is also due to the need for fast publication (Burt and Mcdonnell, 2014); (Vidon, 2015). Modeling and remote sensing play important roles in this area of research, but they do not replace observed data, that are necessary to validate both.

\section{Conclusion}

In this study we evaluated the hydrometeorological monitoring network of the Aquidauana region and whether the current installed ground-based stations are sufficient to monitor the region. Our results indicate that there is a need for installation of more ground-based stations in this region; however, no additional stations would not be necessary if a systematic reactivation existed of the disable ground-based stations.

When compared with the BAP, the Aquidauana region has a better distribution of stations. Thus, an up-todate data collection of the whole area of the Upper Paraguay Basin should be performed in order to check the concentration of stations. A lack of integration was seen between the agencies in charge in relation to concentration of information and proximity of stations.

Using remote sensing data may be possible to fill the hydrometeorological data gap. However, we conclude that to improve the knowledge on hydrological processes in this region is still necessary to install new ground-based data, mainly because remote sensing data and hydrologic modeling need of ground-based data to be evaluated.

\section{Acknowledgments}

This research project is supported by FUNDECT (Foundation to Support the Development of Education, Science and Technology of the State of Mato Grosso do Sul), EMBRAPA (Brazilian Agricultural Research Corporation) and CAPES (Brazilian Federal Agency for Support and Evaluation of Graduate Education within the Ministry of Education of Brazil).

\section{References}

ANA. National Water Agency. Available at www.ana.gov.br, accessed on: 10 Jan. 2015.

HIDROWEB. Shape da bacia e dados pluviométricos. Available at: www.ana.gov.br, accessed on: Feb 10, 2015.

BODIAN, A.; DEZETTER, A.; DEME, A.; DIOP, L. Hydrological evaluation of TRMM rainfall over the upper Senegal river basin. Hydrology, v. 3, n. 15, p. 1-18, 2016. 
BURT, T.P.; MCDONNELL, J.J. Whither field hydrology? The need for discovery science and outrageous hydrological hypotheses. Water Resources Research, v. 51, n. 10, p. 5919-5928, 2015.

DEMBÉLÉ, M.; ZWART, J.S. Evaluation and comparison of satellite-based rainfall products in Burkina Faso, West Africa. International Journal of Remote Sensing, v. 37, n. 17, p. 3995-4014, 2016.

HUGHES, D.A. Comparasion of satellite rainfall data with observations from gauging station networks. Journal of Hydrology, v. 327, n. 10, p. 399-410, 2006.

IBGE. Brazilian Institute of Geography and Statistics. Available at $<$ http://cidades.ibge.gov.br/xtras/perfil.php?codmun $=500110$, accessed on: Feb 13, 2015.

ISHIHARA, J.H.; FERNANDES, L.L.; DUARTE, A. M.; DUART, A.RR.C.; PONTE, M.X.; LOUREIRO, G. E. Quantitative and Spatial Assessment of Precipitation in the Brazilian Amazon. Brazilian Journal of Water Resources, v.19, n. 1, p. 29-39, 2014.

KIDD, C.; BECKER, A.; HUFFMAN, J.G.; MULLER, L.C.; JOE, P.; SKOFRONICK-JACKSON, G.; KIRSCHBAUM, B.D. So, How Much of the Earth's Surface is Covered by Rain Gauges?. American Meteorological Society, v. 10, n. 1, p. 69-78, 2016.
LOUREIRO, G.E.; VIEIRA, A.S.A.; MIRANDA, H.K.S. Análise da Rede Pluviométrica da Região Hidrográfica TocantinsAraguaia e sua Otimização. Brazilian Journal of Water Resources, v. 21, n. 2, p.1-9, 2012.

OLIVEIRA, P.T.S.; LEITE, M.B.; MATTOS, T.; NEARING, M.A.; SCOTT, R.L.; WENDLAND, E. Groundwater recharge decrease with increased vegetation density in the brazilian cerrado. Ecohydrol, v. 10, n. 1, p. 1-8, 2016.

MULLER, C.L.; CHAPMAN, L.; JOHNSTON, S.; KIDD, C.; ILLINGWORTH， S.; FOODY， G.; OVEREEM， A.; LEIGH, R.R. Crowdsourcing for climate and atmospheric sciences: Current status and future potential. Int. J. Climatol, v. 35, n. 11, p. 3185-3203, 2015.

WMO. World Meteorological Organization. Genebra: WMO, n. 168 , ed. $5,1994$.

TUCCI, C.E.M.; COLLISHONN, W. Coupled HydrologicHydraulic Modeling of the Upper Paraguay River Basin. Journal of Hydrologic Engineering. Reston, v. 17, n. 3, p. 635-646, 2012.

WILLINK, W.P.; CHERNOFF, B.; ALONSO. E.L.; MONTAMBAULT, R.J.; LOURIVAL, R. A Biological Assessment of the Aquatic Ecosystems of the Pantanal, Mato Grosso do Sul, Brasil. Washington: RAP Bulletin of Biological Assessment, n. 18, p. 93-98, 2009.

This is an Open Access article distributed under the terms of the Creative Commons Attribution Non-Commercial License which permits unrestricted non-commercial use, distribution, and reproduction in any medium provided the original work is properly cited. 